\title{
Particle-laden Eurasian Arctic sea ice: observations from July and August 1987
}

\author{
STEPHANIE PFIRMAN, JEAN-CLAUDE GASCARD, INGO WOLLENBURG, PETA MUDIE AND \\ ANDREA ABELMANN
}

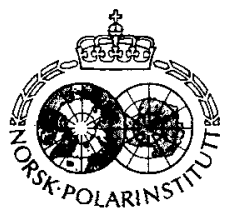

Pfirman, S., Gascard, J.-C., Wollenburg, I., Mudie, P. \& Abelmann, A. 1989: Particle-laden Eurasian Arctic sea ice: observations from July and August 1987. Polar Research 7, 59-66.

During the summer 1987 expedition of the polar research vessel 'Polarstern' in the Eurasian Basin of the Arctic Ocean, sea ice at about $84-86^{\circ} \mathrm{N}$ and $20-30^{\circ} \mathrm{E}$ was found to have high concentrations of particulate material. The particle-laden ice occurred in patches which often darkened more than half the ice surface at our northernmost positions. Much of this ice appeared to be within the Siberian Branch of the Transpolar Drift stream, which transports deformed, multi-year ice from the Siberian shelves westward across the Eurasian Basin. Lithogenic sediment, which is the major component of the particulate material, may have been incorporated during ice formation on the shallow Siberian seas. Diatoms collected from the particlerich ice surfaces support this conclusion, as assemblages were dominated by a marine benthic species similar to that reported from sea ice off the coast of northeast Siberia. Based on drift trajectories of buoys deployed on the ice it appears that much of the particle-laden ice exited the Arctic Ocean through the Fram Strait and joined the East Greenland Current.

Very different sea ice characteristics were found east of the Yermak Plateau and north of Svalbard and Frans Josef Land up to about $83-84^{\circ} \mathrm{N}$. Here sea ice was thinner, less deformed, with lower amounts of lithogenic sediment and diatoms. The diatom assemblage was dominated by planktonic freshwater species. Trajectories of buoys deployed on sea ice in this region indicated a tendency for southward transport to the Yermak Plateau or into the Barents Sea.

Stephanie Pfirman and Ingo Wollenburg, GEOMAR, Research Center for Marine Geosciences, Wischhofstrasse 1-3, Bldg. 4, D-2300 Kiel 14, F.R.G.; Jean-Claude Gascard, Laboratoire d'Océanographie Dynamique et de Climatologie, Tour 14, Université Pierre et Marie Curie, 4 Place Jussieu, 75252 Paris Cedex 05, France; Peta Mudie, Bedford Institute of Oceanography, Atlantic Geoscience Center, P.O. Box 1006, Dartmouth, Nova Scotia, B2Y 4A2, Canada; Andrea Abelmann, Alfred-Wegener Institute for Polar and Marine Research, Postfach 120161, Columbusstrasse, D-2850 Bremerhaven, F.R.G.; October 1988 (revised February 1989).

In July and August 1987 an expedition with the ice-breaker $\mathbf{R} / \mathrm{V}$ 'Polarstern' conducted the first transect of oceanographic stations across the Eurasian Arctic (Fig. 1) since Nansen's epic voyage with the 'Fram' from 1893 to 1896 (Nansen 1897; Polarstern Shipboard Scientific Party 1988; Thiede 1988; Anderson et al. 1989). Sea ice data obtained along this transect represent the first large-scale survey of ice characteristics and particle content analyses from the margin to the interior of the Arctic Basin $\left(81-86^{\circ} \mathrm{N}\right.$ and $15-$ $32^{\circ} \mathrm{E}$ ). Objectives of the sea ice program were to study sea ice dynamics/thermodynamics and the impact of sea ice on sedimentation and biological productivity. This type of information is greatly needed for interpretation of the Arctic sedimentary environment. The role of sea ice versus iceberg rafting of glaciomarine sediments is a highly controversial subject, largely because of limited data on the sediment content and texture of modern sea ice (e.g. Hopkins \& Herman 1981; Spjeldnæs 1981; Clark \& Hanson 1983; Minicucci \& Clark 1983; Larssen et al. 1987; Reimnitz \& Kempema 1988). In this paper we present observations on Eurasian Basin ice characteristics and surface particle accumulations. Our data are based on sea ice coring ( 72 cores were drilled), surface snow and ice sampling (over 100 samples were obtained), helicopter observations and photography, and drift trajectories of satellitetracked buoys (an array of 12 was deployed on ice floes along the cruise track).

Sea ice conditions were characteristic of the melting season but showed distinct variations along the transect into and out of the Eurasian Basin. Ice in the region along the southern perimeter was composed of mixed young and multiyear ice, less compact and deformed than ice to the north, also noted by Overgaard et al. (1983) during an expedition in 1980 ('Ymer'). North 


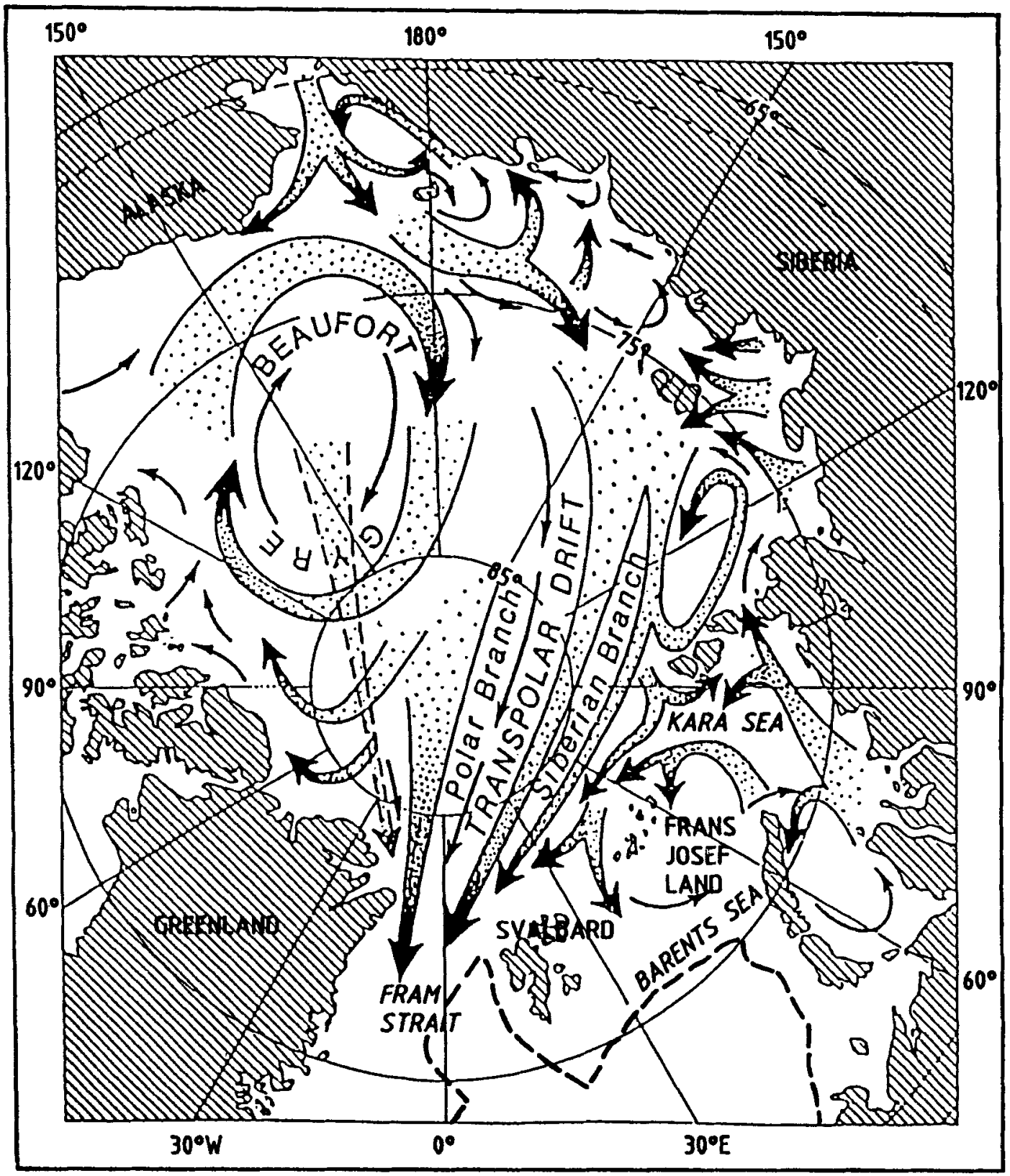

Fig. 1a. Arrows show an early estimate of the mean ice drift (adapted from Gordienko \& Laktionov 1969) and average maximum extent of sea ice (1973-1976, based on the 15\% concentration level, from Parkinson et al. 1987).

of approximately $83-84^{\circ} \mathrm{N}$, in the vicinity of the Siberian Branch of the Transpolar Drift (Fig. 1a), the ice consists predominantly of thick and deformed multiyear floes. This ice is thought to originate in part on the Siberian shelves (Nansen 1897; Koch 1945; Gordienko \& Laktionov 1969; Colony \& Thorndike 1985). The ice surface had deep melt ponds, patches of old snow and bare ice, with rare new snow. Analysis of surface seawater chemistry indicates that the source of freshwater at the northern stations is dominated by river run-off, while in the southern part of the transect the source is mainly sea ice meltwater (Anderson et al. 1989). 


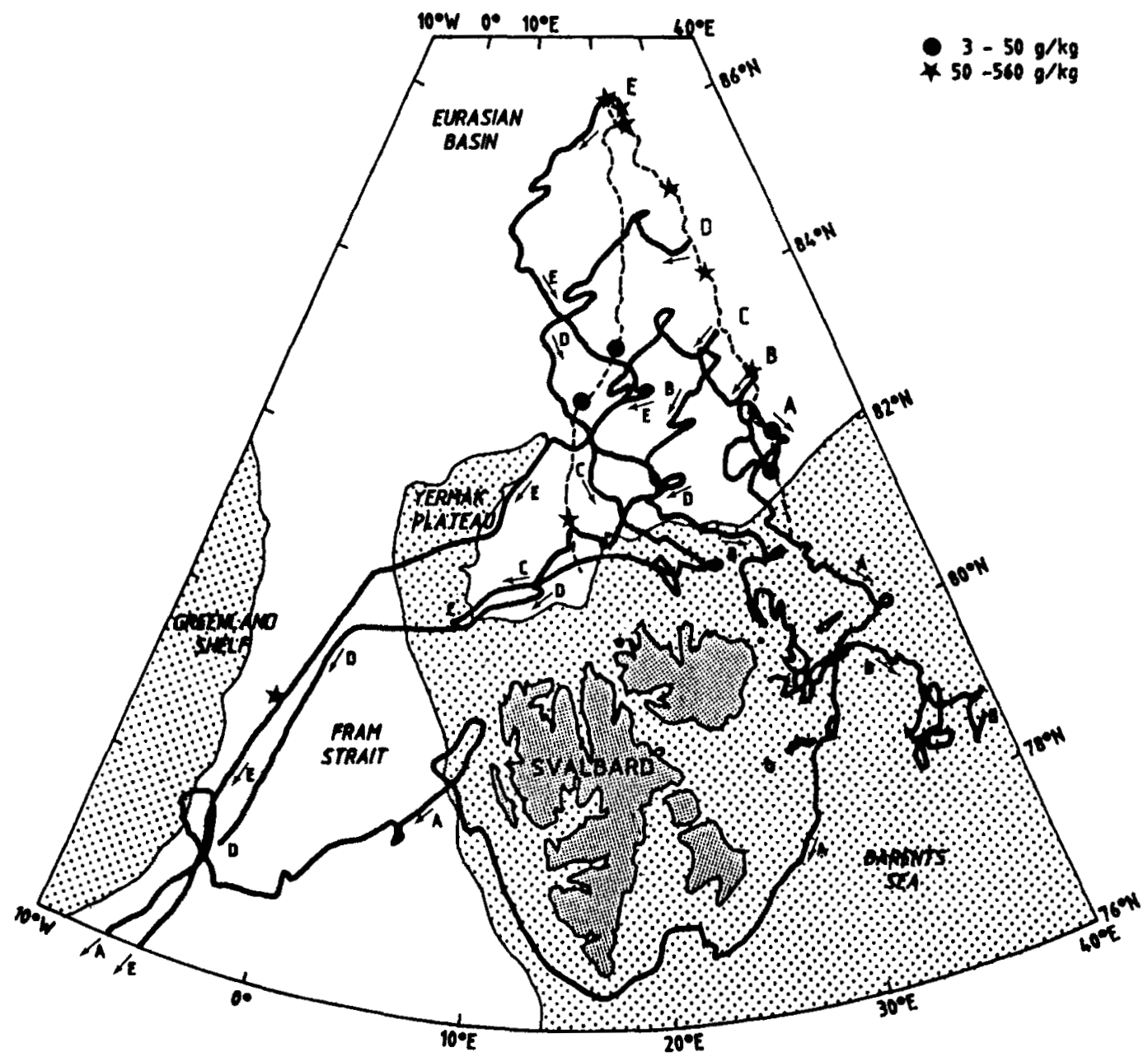

Fig. Ib. Five buoy drift trajectories selected from 12 deployed (solid lines) and the cruise track north of $81^{\circ} \mathrm{N}$ from the $1987 \mathrm{R} / \mathrm{V}$ 'Polarstern' expedition (dashed line) are shown. Symbols indicate location of samples scraped from the ice surface and discussed in the text. Concentrations are in approximate dry weight of particulate matter vs. weight of particle-laden ice. Stippled area represents regions with less than $1000 \mathrm{~m}$ water depth. For details on buoy deployments and station work see Thiede (1988).

\section{Particle-laden sea ice}

Although many Arctic researchers have reported large patches of particle-laden ice (e.g. Clark \& Hanson 1983), quantitative estimates of the percent of sea ice with surface discolorations due to sediment are limited. Drewry (1986) suggests that north of Svalbard as much as $10 \%$ of the ice floes exhibit such discolorations. In the Barents Sea, areal coverage of brownish ice was observed to be as high as $20-30 \%$ of a given ice area (Vinje 1985). Such observations are also difficult to translate into estimates of clastic sediment content because surface particle accumulations 1) may contain a large biogenic component, 2) deposits may be masked by snow, and 3) surface observations exclude particle-rich layers occurring below the ice surface (Larssen et al. 1987).

Our observations from the ship and from helicopter flights show that in summer 1987 particle accumulations affected up to $10 \%$ of the ice surface south of $83^{\circ} \mathrm{N}$, but usually the amount was less than $1 \%$. Highest concentrations of particleladen ice, locally affecting more than half of the ice surface over $10^{\prime} \mathrm{s} \mathrm{km}^{2}$ (Fig. 2a), occurred from $83^{\circ} 30^{\prime} \mathrm{N}$ to our northernmost location at $86^{\circ} 10^{\prime} \mathrm{N}$ (between about $20-30^{\circ} \mathrm{E}$ ) in the region of the 
Siberian Drift Branch. Preliminary analyses of ice cores indicate that the large surface accumulations were associated with multiyear ice (Pfirman et al. 1989). Surficial deposits and particle aggregates extending down to about $15 \mathrm{~cm}$ were most often observed in ice cores, with occasional deeper lenses perhaps caused by rafting of floes over and under each other (Pfirman et al. 1989). Ice which appeared cloudy due to particles disseminated throughout the core section, called turbid ice (Reimnitz \& Kempema 1987), was seldom observed. Often particle accumulations were observed at the base of cylindrical cryoconite (e.g. Poser 1933) holes melted into the ice surface (Fig. $2 b$ ). This feature was also noted by Nansen (1906) on the 'Fram' expedition. In the vicinity of $86^{\circ} \mathrm{N}$ large accumulations of oblate, cohesive pellets of mixed lithogenic and biogenic material up to $3 \mathrm{~cm}$ in diameter were observed. The largest pellets were found in dry holes of 10 to $28 \mathrm{~cm}$ depth (dry means the holes contained no meltwater). Similar large pellets, up to $0.5 \mathrm{~cm}$, are found on multiyear ice along the Canadian polar margin where they consist of fine silty clay and snow algae (Mudie et al. 1986).

Initial studies were carried out on 13 samples scraped from large particle-rich surface accumulations, sometimes in such high concentrations that it appeared like mud on the ice. Total concentrations of biogenic and lithogenic material range from approximately 3 to $560 \mathrm{~g} / \mathrm{kg}$ of particle-rich ice (Fig. 1). Lithogenic sediments predominate with variable admixtures of biogenic material. Grain size of the lithogenic sediments is fairly uniform; they are mainly silt- and claysized, with about $80 \%$ less than $16 \mu \mathrm{m}$ in diameter. The coarse fraction contained quartz and feldspar, with minor mica, glauconite, coal and heavy minerals. At one station, located at $82^{\circ} \mathrm{N}$, $32^{\circ} \mathrm{E}$, surface snow contained a few angular rock fragments of unexplained origin, $2-3 \mathrm{~mm}$ in diameter.

The biogenic component of the surface particle accumulations is dominated by diatoms. Other

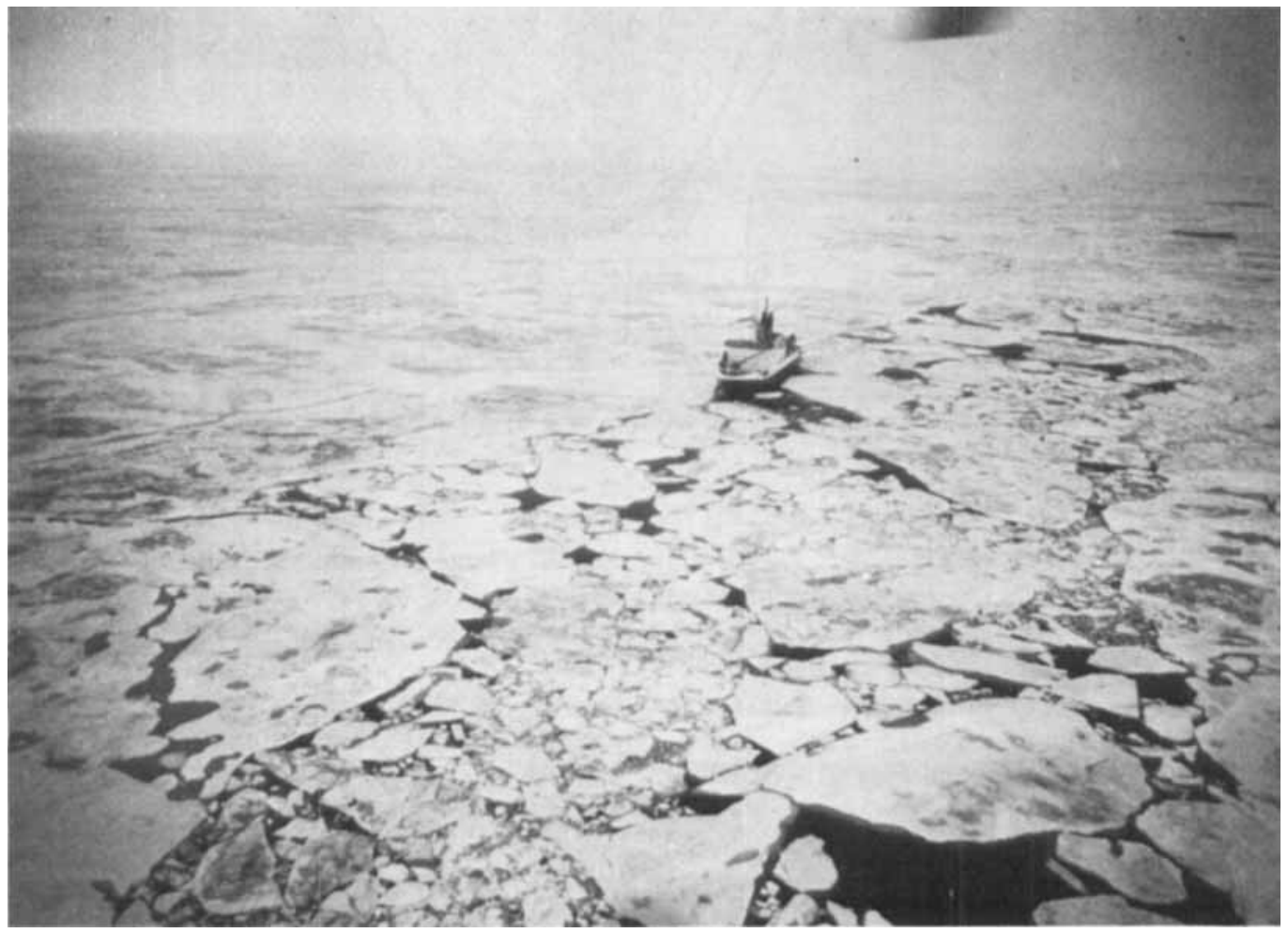

Fig. 2a. Photograph of the R/V 'Polarstern' in a region of particle-laden ice with extensive surface melting at $86^{\circ} 10^{\prime} \mathrm{N}$ and $22^{\circ} 4^{\prime} \mathrm{E}$, our northernmost location. 


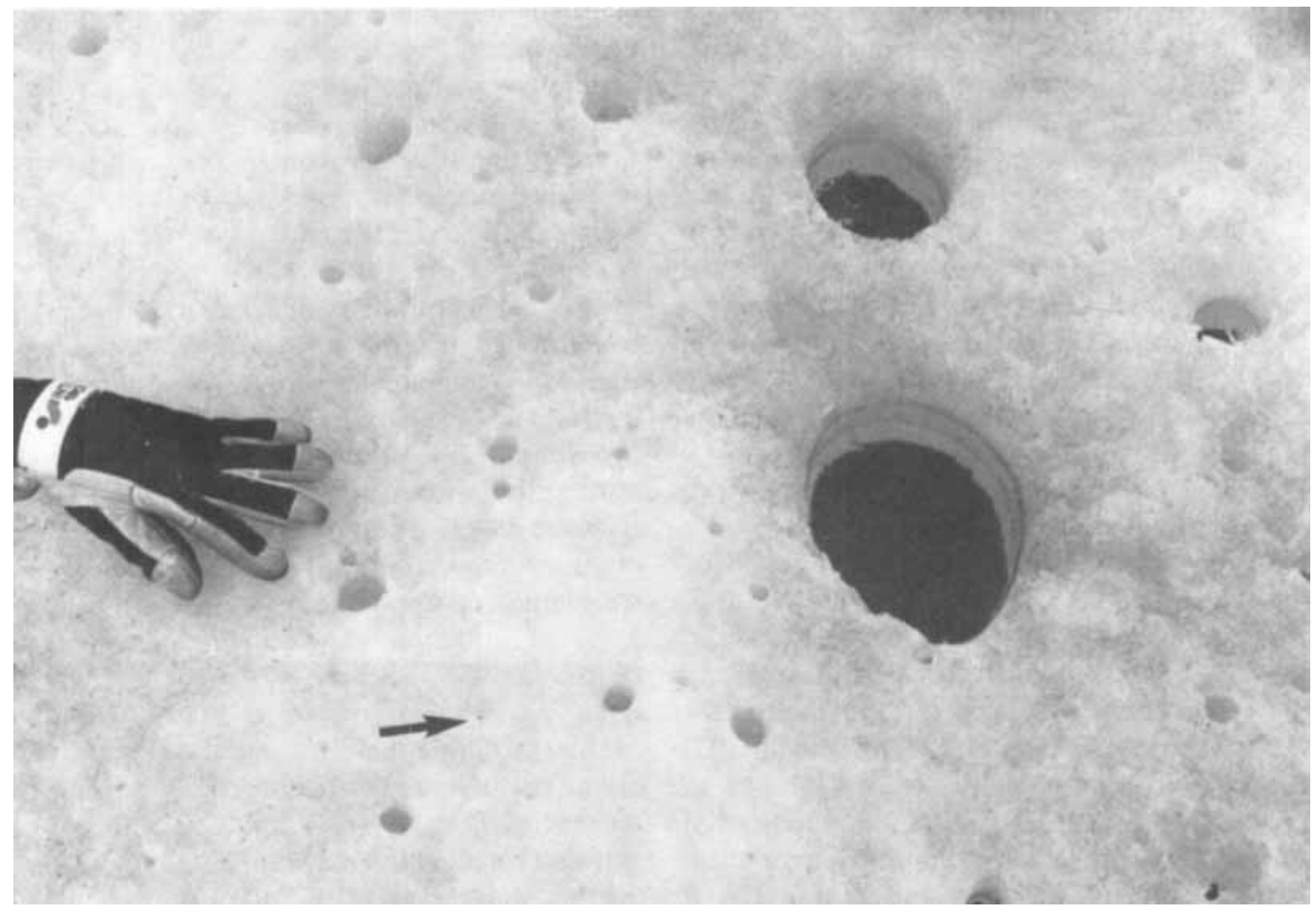

Fig. 2b. Photograph of cylindrical cryoconite holes in the ice surface with accumulations of particulate material at the bottom. The holes are often several $\mathrm{cm}$ in diameter and up to about $20 \mathrm{~cm}$ deep. Arrow points to small aggregate of particulate matter on the ice surface.

biogenic material includes moss leaves, boreal forest or tundra pollen and spores suggesting a terrestrial origin. Logs of wood, up to $40 \mathrm{~cm}$ diameter and $2 \mathrm{~m}$ long, were also found on the ice. All ice samples contained small $(5-30 \mu \mathrm{m})$ Chrysophyte algae including several Archaeomonas species which characterize sea ice on the Canadian polar margin (Federovich 1987) and Antarctic ice (Gersonde 1986). Unicellular organisms with bright red pigment bodies often stained the ice surface. The most common species is Chlamydomonas nivalis, a widespread Arctic-Alpine snow algae.

Diatoms, which compose more than $90 \%$ of the biogenic silicious components in the particleladen surface samples, showed a marked variation in abundance and species assemblage from south to north. Highest diatom concentrations were observed between $84^{\circ}$ and $86^{\circ} \mathrm{N}$, where the assemblage was dominated by marine benthic species. Similar marine benthic diatom communities were described by Cleve (1883) from ice floes off the coast of northeast Siberia (Cape Wankarema) and by Gran (1904) from ice floes sampled during the 'Fram' expedition in the central Eurasian Basin. Marine planktonic diatoms and resting spores contribute smaller numbers but occur consistently in all investigated samples. Benthic freshwater diatoms and terrestrial diatoms were found in traces.

The sea ice south of $84^{\circ} \mathrm{N}$ contains lower numbers of diatoms and the assemblages here contain significant amounts of planktonic freshwater diatoms. In contrast with the northern samples, the content of marine benthic, terrestrial and fossil diatoms is very low. Marine planktonic diatoms have a species composition similar to the northern samples.

\section{Sea ice drift}

Drift of sea ice has been estimated at approximately $1-3 \mathrm{~cm} / \mathrm{sec}$ to the southwest in the Transpolar Drift (Colony \& Thorndike 1984). Observations of trajectories of buoys deployed 
on sea ice during the cruise are consistent with these estimates and mean ice motion appears to be stable over long time periods. One buoy drifted almost exactly over a portion of the path of the 'Fram' (Nansen 1902; Polarstern Shipboard Scientific Party 1988) at comparable speeds and directions.

Variability of sea ice drift is the result of the combined effects of winds and currents; temporal variability is largely due to wind. For example, the peculiar sea ice drift pattern which occurred during our expedition from the end of July to the beginning of August (the loop developed shortly after deployment, see Fig. 1b) was associated with a sequence of southerly winds alternating with easterlies and westerlies. During this period, buoy drifts are extremely coherent (Fig. 1b). Reversal of ice drift from the mean appears to be a common feature in the summer in this area. The 'Fram' expedition nearly 100 years ago experienced the same phenomenon (Nansen 1902), as did the 1937 drift of 'North Pole 1' (Papanin 1947).

During fall and winter 1988, buoys deployed north of $84^{\circ} \mathrm{N}$ had more regular drift tracks which were similar to the expected ice drift (Fig. 1b). It is apparent from the buoy trajectories that much of the sea ice in this region drifted out of the Eurasian Basin through the Fram Strait and was incorporated in the East Greenland Current (e.g. buoys ' $D$ ' and ' $E$ ', Fig. 1b). In contrast, buoys deployed on sea ice south of $84^{\circ} \mathrm{N}$ were later tracked to the Yermak Plateau (e.g. buoy ' $C$ ', Fig. 1b) or into the Barents Sea (e.g. buoys ' $A$ ' and 'B', Fig. 1b). One of these buoys ('A', Fig. 1b) drifted out of the Barents Sea south of Svalbard, turned north along the western Svalbard margin, drifted west across the Fram Strait, and finally joined the East Greenland Current.

\section{Geologic significance}

Because sediments are likely to be incorporated during sea ice formation on shallow seas (e.g. Barnes \& Reimnitz 1974; Reimnitz \& Barnes 1974; Barnes et al. 1982; Osterkamp \& Gosink 1984; Reimnitz \& Kempema 1987; Reimnitz et al. 1987), it is probable that lithogenic sediments sampled on the Siberian Drift ice were included when the ice formed originally on the Siberian shelves (Nansen 1897; Koch 1945; Gordienko \& Laktionov 1969; Colony \& Thorndike 1985; Larssen et al. 1987). This conclusion is supported by similarity of the associated benthic marine diatom assemblage to that sampled on ice floes off the coast of northeast Siberia (Cleve 1883). During drift across the Eurasian Basin, aeolian transport most likely contributes only minor additional particulate material, but may redistribute particles on the pack ice surface (Mullen et al. 1972; Darby et al. 1974; Pfirman et al. 1989).

Seasonal melting of particle-laden multiyear ice concentrates material suspended in the ice and whatever is added later through wind transport, forming surface accumulations (Nansen 1904; Sverdrup 1929). Biologic productivity during summer will also increase surface particle loads (Nansen 1906). The combination of these two processes may explain why particle accumulations were largest on the surface of the ice. Large areal extent of surface particle accumulations observed in summer 1987 indicates large-scale sediment input.

Due to differential absorption of solar radiation, particles aggregate in variable-sized cylindrical pits, called cryoconite holes, on the surface (Fig. 2; Nansen 1906; Poser 1933). Compaction and periodic desiccation during freeze/ thaw cycles may combine to form $\mathrm{mm}$ - or $\mathrm{cm}$ scale pellets such as those we observed at our northernmost stations (Barnes \& Reimnitz 1974; Pfirman et al. 1989). Cryoconite formation and aggregation of particles may be important in accelerating sedimentation of originally finegrained material to the sea floor. Furthermore, sea floor accumulations of such pellets may indicate deposition from sediment-laden sea ice (Goldstein 1983).

Buoy trajectories show that in 1987 the majority of sampled particle-laden ice was transported out of the Eurasian Basin through the Fram Strait and into the East Greenland Current. Under present conditions ice melting and release of particle load is therefore likely to occur in the marginal ice zone east of Greenland. However, evidence from sea floor sediment cores obtained during the expedition may indicate extensive ice melting in the Eurasian Arctic in the past. Sea-floor sediment cores from the Nansen-Gakkel Ridge (about $85^{\circ} 20^{\prime}-86^{\circ} \mathrm{N}$ and $21-27^{\circ} \mathrm{E}$ ), the Yermak Plateau, and the Fram Strait contain thick sections $(10$ 's to 100 's $\mathrm{cm}$ ) at various depths consisting largely of distinct mud clasts (Polarstern Shipboard Scientific Party 1988; Spielhagen \& Pfirman 1988; Thiede 1988). Goldstein (1983) suggests that pack ice and iceberg rafted clasts (Ovenshine 1970; 
Clark et al. 1980; Minicucci \& Clark 1983) may be distinguished from each other by sediment grain size, i.e. clasts formed in glacier ice are more likely to be coarse-grained. Preliminary investigation of a few clasts from the Eurasian Basin sea floor sediment cores indicates that the clasts are composed of fine-grained mud apparently similar to the matrix. Resting spores of Archaeomonas spp. and Chlamydomonas nivalis which are typical of sea ice were also identified. This information suggests that the sea floor mud clasts and sea ice pellets are genetically linked. Observations of thick sequences of such pellets in Eurasian Basin sediment cores therefore may indicate significant deposition from sea ice in these regions.

Sea ice characteristics east of the Yermak Plateau and north of Svalbard and Frans Josef Land up to $83-84^{\circ} \mathrm{N}$ indicate a source different than the Siberian Drift ice. Because most of the ice appeared to be thinner, less deformed, and had relatively low lithogenic sediment concentrations, it may have formed more locally over deeper water and farther from shore than ice to the north. Trajectories of buoys deployed on this relatively particle-poor sea ice indicated southward transport either to the Yermak Plateau or into the Barents Sea in late 1987 . Observations by Vinje (1985) of particle-laden ice in the Barents Sea are not in conflict with these data because: 1) there are likely to be seasonal and annual variations in ice drift (Koch 1945; Zacharov 1976; Vinje 1985), 2) Siberian ice may also enter the Barents Sea to the east through straits west or south of Frans Josef Land, and 3) the particle-laden ice in the Barents Sea could have sources within the Kara Sea or the Barents Sea itself, although the Barents Sea is considered an unlikely source area (Elverhøi et al. 1989).

Acknowledgements. - We thank Jörn Thiede, GEOMAR, Research Center for Marine Geosciences, chief scientist on the 1987 expedition, Manfred Lange, Alfred-Wegener Institute for Polar and Marine Research, for arranging loan of ice sampling equipment, Susumo Honjo, Woods Hole Oceanographic Institution, for providing sampling materials, the Captain, Heinz Jonas, and crew of R/V 'Polarstern', C. Richez, Laboratoire d'Océanographie Dynamique et de Climatologie for assisting in analysis of buoy drift trajectories, and the two anonymous reviewers. We acknowledge financial support from the Bundesministerium für Forschung und Technologie, the Deutsche Forschungsgemeinschaft, the United States Office of Naval Research, the French Institut National des Sciences de l'Univers, Centre National d'Etudes Spatiales, Institut Français de Recherches et d'Exploitation de la Mer, and the Geological Survey Canada. We recognize the assistance of other members of the shipboard sea ice working party: A. Altenbach, K. P. Koltermann, R. Krishfield, B. Richter, H. Sonnabend and U. Stute. We also thank Sigrid Federovich, Geological Survey Canada (Ottawa) and Rainer Gersonde, Alfred-Wegener Institute for Polar and Marine Research, for their help with Chrysophyte and diatom studies.

\section{References}

Anderson, L. G., Jones, E. P., Koltermann, K. P., Schlosser, P., Swift, J. H. \& Wallace, D. W. R. 1989: The first oceanographic section across the Nansen Basin in the Arctic Ocean. Deep-Sea Res. 36(3), 475-482.

Barnes, P. W. \& Reimnitz, E. 1974: Sedimentary processes on Arctic Shelves off the northern coast of Alaska. Pp. 439-476 in Reed, J. C. \& Sater, J. E. (eds.): The Coast and Shelf of the Beaufort Sea. Arctic Institute of North America, Arlington, Virginia.

Barnes, P. W., Reimnitz, E. \& Fox, D. 1982: Ice rafting of fine-grained sediment, a sorting and transport mechanism, Beaufort Sea, Alaska, J. Sediment. Petrol. 52(2), 493-502.

Clark, D. L. \& Hanson, A. 1983: Central Arctic Ocean sediment texture: Key to ice transport mechanisms. Pp. 301-330 in Molnia, B. F. (ed.): Glacial-Marine Sedimentation. Plenum Press, New York.

Clark, D. L., Whitman, R. R., Morgan, K. A. \& Mackay, S. D. 1980: Stratigraphy and glacial-marine sediments of the Amerasian Basin, central Arctic Ocean. Geol. Soc. Am. Spec. Paper 181. $57 \mathrm{pp}$.

Cleve, P. T. 1883: Diatoms, collected during the Expedition of the 'Vega'. Vega-Expeditions vetenskapliga iakttagelser III.

Colony, R. \& Thorndike, A. S. 1984: An estimate of the mean field of Arctic sea ice motion. J. Geophys. Res. 89(C6), 10623-10629.

Colony, R. \& Thorndike, A. S. 1985: Sea ice motion as a drunkard's walk. J. Geophys. Res. 90(C1), 965-974.

Darby, D. A., Burckle, L. H. \& Clark, D. L. 1974: Airborne dust on the Arctic pack ice, its composition and fallout rate. Earth Planet. Sci. Lett. 24(2), 166-172.

Drewry, D. 1986: Glacial Geologic Processes. Edward Arnold, London. $276 \mathrm{pp}$

Elverhøi, A., Pfirman, S. L., Solheim, A. \& Larssen, B. B. 1989: Glaciomarine sedimentation in epicontinental seas exemplified by the northern Barents Sea. Pp. 225-250 in 'Modern Glacimarine Environments'. Glacial and Marine Controls of Modern Lithofacies and Biofacies. Mar. Geol. 85.

Federovich, S. 1987: Marine Chrysophyte cysts from the Canadian High Arctic. Pp. 68-70 in Proceedings of the International Meeting on the Canadian Arctic Islands. Canadian National Museum, Ottawa.

Gersonde, R. 1986: Siliceous microorganisms in sea ice and their record in sediments in the southern Weddell Sea (Antarctica). Pp. 549-566 in Ricard, M. (ed.): Proceedings of the Eighth International Diatom Symposium. Paris, Koelz, Königstein. Goldstein, R. H. 1983: Stratigraphy and sedimentology of icerafted and turbidite sediment, Canada Basin, Arctic Ocean. Pp. 367-400 in Molnia, B. F. (ed.): Glacial-Marine Sedimentation. Plenum Press, New York.

Gordienko, P. A. \& Laktionov, A. F. 1969: Circulation and physics of the Arctic Basin waters. Pp. 94-112 in Annals of the International Geophysical Year, XLVI Oceanography. Pergamon Press. 
Gran. H. H. 1904: Diatomaceae from the ice-floes and plankton of the Arctic Ocean. In Nansen. F. (ed.): The Norwegian North Polar Expedition 1893-1896. Scientific Results 411). Longmans. Green and Company. London. $74 \mathrm{pp}$.

Hopkins. D M. \& Herman, Y. 1981: Ice rafting, an indication of glaciation? Science 214(4521), 688.

Koch. L. 1945: The East Greenland Ice. Meddelelser om Gronland $130(3) .373 \mathrm{pp}$

Larssen, B. B., Elverhøi. A. \& Aagaard. P. 1987: Study of particulate material in sea ice in the Fram Strait - a contribution to paleoclimatic research? Polar Res. 5(3). 313-315.

Minicucci. D. A. \& Clark. D. L. 1983: A late Cenozoic stratigraphy for glacial-marine sediments of the eastern Alpha Cordillera. central Arctic Ocean. Pp. 331-365 in Molnia. B. F. (cd.): Glacial-Marine Sedimentation. Plenum Press. New York.

Mudie. P. J., Dabros. M. J. \& Redden, A. 1986: Ice island sampling and investigation of sediments field report 1986. Geological Survey Canada Open File Report $1950.36 \mathrm{pp}$

Mullen. R. E., Darby. D. A. \& Clark. D. L. 1972: Significance of atmospheric dust and ice rafting for Arctic Ocean sediment. Geol. Soc. Am. Bull. 83(1), 205-211.

Nansen. F. 1897: Farthest North. Archibald, Constable and Co. Westminster. $510 \mathrm{pp}$.

Nanscn. F. 1902: The oceanography of the North Polar Basin. In Nansen. F. (ed.): The Norwegian North Polar Expedition 1893-1896. Scientific Results 319). Longmans. Green and Company. London. $427 \mathrm{pp}$.

Nansen. F. 1904: The bathymetrical features of the North Polar Seas. with a discussion of the continental shelves and previous oscillations of the shore-line. In Nansen. F. (ed.): The Norwegian North Polar Expedition 1893-1896. Scientific Results 4(13). Longmans, Green and Company. London. 232 pp.

Nansen. F. 1906: Protozoa on the ice-fioes of the North Polar Sca. In Nansen. F. (ed.): The Norwegian North Polar Expedition 1893-1896. Scientific Results 5(16). Longmans. Green and Company, London. 22 pp.

Osterkamp. T. E. \& Gosink. J. P. 1984: Observations and analyses of sediment-laden sea ice. Pp. 73-93 in Barnes, P. W.. Schell. D. M. \& Reimnitz. E. (eds.): The Alaskan Beau. fort Sea, Ecosystems and Environments. Academic Press. Inc., Orlando, Florida.

Ovenshine. A. T. 1970: Observations of iceberg rafting in Glacier Bay. Alaska, and the identification of ancient icerafted deposits. Geol. Soc. Am. Bull. 81(3). 891-894.

Overgaard. S., Wadhams. P. \& Leppäranta. M. 1983: Ice properties in the Greenland and Barents Seas during summer. $J$ Glaciol. 29(101), 142-164.
Papanin, J. D. 1947: Das Leben auf einer Eisscholle: Ein Tagebuch. SWA-Verlag. Berlin. 323 pp.

Parkinson, C. L., Comiso, J. C., Zwally, H. J., Cavalieri, D. J.. Gloersen, P. \& Campbell, W. J. 1987: Arctic Sea Ice, 1973-1976: Satelite passive-microwave observations. NASA SP-489. National Aeronautics and Space Administration, Washington. D.C. $296 \mathrm{pp}$.

Pfirman, S. L., Wollenburg, I., Thiede, J. \& Lange, M. A 1989: Lithogenic sediment on the Arctic pack ice: Potential aeolian flux and contribution to deep sea sediments. NATO Advanced Research Workshop on Modern and Past Patterns of Global Atmospheric Transport (in press).

Polarstern Shipboard Scientific Party 1988: Breakthrough in Arctic deep-sea research: The $\mathrm{R} / \mathrm{V}$ Polarstern expedition 1987. Eos 69(25), 665. 676-678.

Poser. H. 1933: Über Abschmelzformen auf dem ostgrönländischen Packeise und Landeise. Zeit. f. Gletscherk. 21, 120.

Reimnitz, E. \& Barnes, P. W. 1974: Sea ice as a geological agent on the Beaufort Sca shelf of Alaska. Pp. 301-351 in Recd. J. C. \& Sater, J. E. (cds.): The Coast and Shelf of the Beaufort Sea. Arctic Institute of North America, Arlington, Virginia.

Reimnitz. E. \& Kempema, E. W. 1987: Field observations of slush ice generated during freeze-up in Arctic coastal waters. Mar. Geol. 77, 219-231.

Reimnitz. E. \& Kempema, E. W. 1988: Ice rafting: an indication of glaciation? J. Glaciol. 34(117), 254 255 .

Reimnitz. E. Kempema, E. W. \& Barnes, P. W. 1987; Anchor ice, seabed freezing, and sediment dynamics in shallow Arctic seas. J. Geophys. Res. 92(C13), 14671-14678.

Spielhagen. R. \& Pfimman, S. (eds.) 1988: Geoscientific report on the ARK IV $/ 3$ expedition of the PFVS 'Polarstern', summer 1987. to the central eastern Arctic Basin. Berichte Geologisch-Paläontologisches Institut und Museum der ChristianAlbrechts-Universität zu Kiel 24. $166 \mathrm{pp}$.

Spjeldnæs, N. 1981: lce rafting, an indication of glaciation? Science 214(4521), 687-688.

Sverdrup. H. U. 1929; The waters on the north Siberian Shelf. The Norwegian North Polar Expedition with the 'Maud' 19181925. Sci. Res. 4(2). Bergen. 131 pp.

Thiede. J. (ed.) 1988: Scientific Cruise Report of Arctic Expedition ARK IV/3. Reports on Polar Research (AWI) 43 $237 \mathrm{pp}$.

Vinje. T. 1985: Drift, composition, morphology and distribution of the sea ice fields in the Barents Sea. Norsk Polarinst. Skr. $179 \mathrm{C} .26 \mathrm{pp}$.

Zacharov, V, F, 1976: Cooling of the Arctic and the ice cover of the Arctic seas. AANII Trudy 337(94). 96 pp. (Soviet text translated by Norsk Polarinstitutt, Oslo). 